\title{
Analisis Yuridis Terhadap Pengadaan Barang dan Jasa Guna Mencegah Korupsi
}

\section{BERIDIANSYAH}

\author{
Satbrimob Polda Jambi
}

Berdi.wira@gmail.com

p-ISSN : 2477-118X

\section{ABSTRAK}

Tujuan pembangunan nasional sebagaimana yang tercantum dalam Undang-Undang Dasar 1945, untuk melindungi segenap bangsa dan seluruh tumpah darah Indonesia, memajukan kesejahteraan umum, mencerdaskan kehidupan bangsa, serta ikut melaksanakan ketertiban dunia yang berdasarkan kemerdekaan abadi dan keadilan sosial. Upaya untuk mencapai tujuan itu dengan melaksanakan pembangunan sarana dan prasarana yang dilakukan melalui proses pengadaan barang dan jasa pemerintah dengan prinsip efisien, efektif, terbuka dan bersaing, transparan, adil dan tidak diskriminatif serta akuntabel. Sistem pengadaan barang jasa yang ada saat ini terus dilakukan revisi terhadap regulasi yang mengatur sistem tersebut. Salah satunya, kualifikasi orang yang berwenang dan cakap menurut undang-undang untuk melaksanakan pengadaan barang dan jasa tersebut. Penulis berpendapat bahwa sistem yang baik harus didukung oleh Sumber Daya Manusia (SDM) yang qualified, pengalaman serta moral dan etika yang baik. Penulisan ini akan mengkaji 
dua permasalahan, yaitu pertama peranan lembaga-lembaga dalam sistem pengadaan barang dan jasa untuk mencegah terjadinya tindak pidana korupsi. Kedua, pertanggungjawaban pidana terhadap penyalahgunaan wewenang pada pengadaaan barang dan jasa. Penelitian mempergunakan metode yuridis normatif, hasil penelitiannya diharapkan mencapai tujuan pembangunan dan kesejahteraan masyarakat, serta tidak terjadi kebocoran pada anggaran negara oleh oknum-oknum yang menyalahgunakan kewenangan.

Kata kunci: Pengadaan barang dan jasa, Tindak Pidana Korupsi, Peraturan Perundang-undangan.

\section{A B S TRA C T}

National development objectives as contained in of Undang-Undang Dasar 1945 is to protect the people and the country of Indonesia, promote the general welfare, the intellectual life of the nation, as well as participate in the establishment of world order based on freedom eternal and social justice, efforts to achieve these objectives is to implement infrastructure development is done through a process of government procurement of goods and services to the principle of efficient, effective, open and competitive, transparan, fair and non-discriminatory and accountable. Procurement of goods and services that exist today continues to be revision of the regulations governing the system. One of them is the qualifications of the person authorized and competent by law to carry out procurement of goods and services, the authors found a good system must be supported by Human Resources (HR) is qualified, experience and good morals and ethics. This paper will examine two (2) problems: first how the role of the institutions in the system of procurement to prevent corruption? Second How criminal liability against the abuse of authority in providing goods and services? Research using yuridis normatif methods the research results are expected by the a good system will be able to achieve the goals of development and welfare of the community and does not happen again leakage of funds the 
state budget by elements that are irresponsible thinking only of selfinterest by abusing its authority.

Keywords: Procurement, Corruption, Legislation.

\section{PENDAHULUAN}

Konsep good governance muncul pertama kali diadopsi para praktisi di lembaga pembangunan internasional, yang mengandung konotasi kinerja efektif yang terkait dengan manajemen publik dan korupsi. Munculnya konsep tersebut berawal dari adanya kepentingan lembaga-lembaga donor seperti Perserikatan Bangsa-Bangsa (PBB), Bank Dunia, Asian Development Bank (ADB) maupun International Monetary Fund (IMF) dalam memberikan bantuan pinjaman modal kepada negara-negara berkembang. Dalam perkembangan selanjutnya, good governance ditetapkan sebagai syarat bagi negara yang membutuhkan pinjaman dana, sehingga good governance dijadikan standar penentu untuk mencapai pembangunan berkelanjutan dan berkeadilan (Sadjijono, 2005:179).

Sejalan dengan konsep good governance, Indonesia telah menetapkan arah dan tujuan pembangunannya sebagaimana yang tercantum dalam Undang-Undang Republik Indonesia Nomor 17 Tahun 2007 tentang Rencana Pembangunan Jangka Panjang Nasional, Ketetapan Majelis Permusyawaratan Rakyat Republik Indonesia Nomor III/MPR/1993 Tentang Garis-Garis Besar Haluan Negara (GBHN) serta dalam Pembukaan Undang-Undang Dasar 1945, dijelaskan arah dan tujuan perekonomian dan pembangunan bangsa Indonesia, yaitu melindungi segenap bangsa dan seluruh tumpah darah Indonesia, memajukan kesejahteraan umum, mencerdaskan kehidupan bangsa, serta ikut melaksanakan ketertiban dunia yang berdasarkan kemerdekaan, perdamaian abadi, dan keadilan sosial. Untuk merealisasikan tujuan pembangunan nasional itu, pemerintah melakukan pembenahan terhadap sistem yang ada, sehingga harapan segenap rakyat Indonesia dapat segera diwujudkan. Transformasi tata kelola pemerintah saat ini semakin mengarah pada penyeleng- 
garaan pemerintah yang berbasis tata kelola pemerintahan yang baik (the principles of good administration), sebagai pelaksana pemerintahan negara yang dibentuk atas dasar kepercayaan (trust) publik dan keniscayaan (availability) negara. Selain itu, dalam menjalankan berbagai aktivitasnya wajib menjalankan prinsip-prinsip kepemerintahan yang baik (good governance) yang akan menghasilkan kesejahteraan rakyat dalam negara kesejahteraan (welfare state).

Untuk mewujudkan good governance, Indonesia membutuhkan bantuan negara lain sebagaimana yang disebutkan oleh Thomas Hobbes "Homo Homini socius" atau manusia sebagai "Zoon Politicon" sebagaimana yang dinyatakan oleh Aristoteles bahwa manusia dikodratkan untuk hidup bermasyarakat dan berinteraksi satu sama lain, sebuah hal yang membedakan manusia dengan hewan.

Mewujudkan kepemerintahan yang baik (good governance) harus didukung oleh Sumber Daya Manusia (SDM), aturan dan moral dari aparatur pelaksana yang harus baik. Namun, hambatan nyata dalam mewujudkan kesejahteraan masyarakat serta untuk mewujudkan kepemerintahan yang baik adalah masih tingginya tingkat penyalahgunaan keuangan negara oleh oknum-oknum yang tidak bertanggung jawab dan menyebabkan kerugian negara yang sangat besar, sehingga diperlukan sistem dan aturan yang dapat mengakomodasi persoalan-persoalan tersebut. Konsep good governance itu terwujud jika pemerintahan diselenggarakan dengan transparan, responsif, partisipatif, taat pada ketentuan hukum (Rule of Law), berorientasi pada konsensus adanya kebersamaan, akuntabilitas, dan memiliki visi yang strategis (Sadjijono, 2005:182).

Peraturan Presiden Nomor 4 Tahun 2015 tentang Perubahan Keempat tentang Pengadaan Barang dan Jasa, lahir sebagai jawaban pemerintah untuk memperbaiki sistem pengelolaan keuangan negara melalui pengadaan barang dan jasa. Untuk membahas sejauh mana kontribusi pengadaan barang dan jasa terhadap pencegahan tindak pidana korupsi, maka dalam penulisan ini akan membahas dua permasalahan, yaitu pertama bagaimana peranan lembagalembaga dalam sistem pengadaan barang dan jasa pemerintah untuk 
mencegah terjadinya tindak pidana korupsi? Kedua, bagaimana pertanggungjawaban pidana terhadap penyalahgunaan wewenang pada pengadaan barang dan jasa? Penulisan ini sangat penting karena sebagaimana yang dirilis oleh CNN Indonesia, bahwa penanganan kasus korupsi sepanjang tahun 2016 mencapai 453 perkara menempati urutan kedua setelah kasus narkotika mencapai 800 perkara.

\section{TINJAUAN TEORITIS}

Tindak pidana terhadap penyalahgunaan wewenang, khususnya korupsi pada pengadaan barang dapat menimbulkan kerugian yang sangat besar terhadap pembangunan bangsa. Untuk dapat mewujudkan amanat sila kelima Pancasila diperlukan moral dan sistem yang baik, yaitu struktur hukum (Structure of the Law), substansi hukum (Substance of the Law), dan budaya hukum (Legal Culture). Struktur hukum menyangkut aparat penegak hukum, substansi hukum meliputi perundang-undangan, dan budaya hukum merupakan hukum yang hidup yang dianut dalam suatu masyarakat.

Untuk menciptakan sistem yang baik, diperlukan peran pengawasan untuk tegaknya peraturan pengadaan barang dan jasa. Menurut Travis Hirschi bahwa diperlukan pengawasan yang kuat untuk mencegah terjadinya kejahatan, "The stronger these bonds, the less likelihood of delinquency". Untuk mencegah terjadinya kejahatan tersebut dibutuhkan attachment, commitment, involment dan belief. Tingkah laku jahat timbul karena tidak ada keterikatan moral pelaku terhadap masyarakat serta lemahnya ikatan-ikatan yang berkaitan dengan tingkah laku, "Weakness in any of the bonds was associated with delinquent behavior."

Dengan adanya sistem serta moral yang baik aparat yang melaksanakan peraturan tersebut maka tujuan hukum, yaitu kepastian hukum, kemanfaatan, dan keadilan, dapat terwujud. 


\section{PENYAJIAN DATA}

Pengadaan barang dan jasa dilaksanakan untuk mencapai keadilan dan kesejahteraan bagi masyarakat. Namun pada pelaksanaannya, banyak menimbulkan permasalahan hukum dan menyebabkan kerugian negara yang tidak sedikit. Pada penulisan ini, penulis menyajikan beberapa contoh kasus pengadaan barang dan jasa yang menyebabkan kerugian negara. Beberapa permasalahan hukum yang terjadi pada pengadaan barang dan jasa Pemerintah Provinsi Jambi yang menyebabkan terjadinya kerugian negara antara lain:

1. Kasus pertama, yaitu Tindak Pidana Korupsi Proyek Pengadaan Kapal kayu 3 GT sebanyak 100 unit dengan Surat Perjanjian Kerja No.523/203/SPK/kapal 3 GT/X/2011 tanggal 11 Oktober 2011 senilai Rp.3.488.804.000 (Tiga miliar empat ratus delapan puluh delapan juta delapan ratus empat ribu rupiah) yang bersumber dari APBD Perubahan Kabupaten Tanjung Jabung Timur TA. 2011 di Dinas Kelautan dan Perikanan Kabupaten Tanjung Jabung Timur, yang diduga dilakukan oleh tersangka ISWANTO Bin SUPARTO Konsultan Pengawas, melanggar Pasal 55 ayat (1) ke 1 KUHP Yo Pasal 2, Pasal 3 dan pasal 9 Undang-Undang Republik Indonesia No. 31 tahun 1999 sebagaimana telah diubah dengan Undang-Undang No. 20 tahun 2001 tentang Pemberantasan Tindak Pidana Korupsi;

2. Kasus kedua, yaitu Tindak pidana korupsi dalam pengadaan 48 unit laptop untuk siswa berprestasi di SMAN Titian Teras Jambi pada Dinas Pendidikan Prov. Jambi TA. 2012, yang bersumber dari APBD Dinas Pendidikan Prov. Jambi TA. 2012 yang dalam kegiatan tersebut dikerjakan oleh pihak rekanan tidak sesuai dengan spesifikasi barang yang ditetapkan sesuai dengan Surat Perjanjian Kerja (Kontrak) Nomor: SPK 116/DISDIK 3.1/VI/2012 tanggal 08 Juni 2012 senilai Rp.552.478.000 (Lima ratus lima puluh dua juta empat ratus 
tujuh puluh delapan ribu rupiah) termasuk pajak, melanggar Pasal 2 ayat (1) atau Pasal 3 Undang-Undang Republik Indonesia No. 31 tahun 1999 tentang Pemberantasan Tindak Pidana Korupsi sebagaimana telah diubah dengan UndangUndang No. 20 tahun 2001 tentang Perubahan Atas UndangUndang No. 31 tahun 1999 tentang Pemberantasan Tindak Pidana Korupsi Jo pasal 55 (1) ke 1 KUHP, yang dilakukan oleh Tersangka NIA KURNIASIH selaku Kuasa Direktur CV. Gelora Nusantara;

3. Kasus ketiga, yaitu Dugaan terjadinya Tindak Pidana Korupsi Pengadaan Timbangan Portable pada Dinas perhubungan Kab. Batanghari Jambi TA 2010 yang dilakukan oleh tersangka M. ILYAS ARAS, BBA, RAMBAT AHMAD Bin NASRAN dan DEWAN RICHARDI Bin AKMAL (Selaku Panitia Pemeriksa Barang) sebagaimana dimaksud dalam pasal 2 dan pasal 3 UU No. 31 tahun 1999 sebagaimana telah diubah menjadi UU No. 20 tahun 2001 yo pasal 55 ayat (1) ke-1.

\section{PEMBAHASAN}

\section{Peranan Lembaga pada Sistem Pengadaan Barang dan Jasa}

Perkembangan perekonomian global saat ini begitu cepat, setiap negara dituntut untuk menyelenggarakan sistem perekonomiannya secara bersih dan transparan. Indonesia sebagai bagian dari negara-negara di dunia dalam upaya memenuhi kebutuhan rakyatnya, membutuhkan interaksi dengan negara lain. Karena itu, pemerintah berkewajiban menyediakan kebutuhan rakyat berupa barang, jasa, maupun pembangunan infrastruktur. Untuk dapat terlaksananya pembangunan tersebut dengan tertib dan tidak melanggar hukum, pemerintah telah membuat peraturan dan ketentuan yang mengatur tentang lembaga penyelenggara pengadaan barang dan jasa.

Pengadaan barang dan jasa pemerintah sebagaimana yang dimaksud dalam Peraturan Presiden Nomor 4 Tahun 2015 tentang Pe- 
rubahan Keempat atas Peraturan Presiden Nomor 54 Tahun 2010 tentang Pengadaan Barang/Jasa Pemerintah adalah kegiatan untuk memperoleh barang/jasa oleh Kementerian/Lembaga/Satuan Kerja Perangkat Daerah/Institusi yang prosesnya dimulai dari perencanaan kebutuhan sampai diselesaikannya seluruh kegiatan untuk memperoleh barang/jasa. Sistem yang ditetapkan dalam pengadaan barang dan jasa adalah dalam rangka percepatan pelaksanaan belanja negara guna percepatan pelaksanaan pembangunan dengan pemanfaatan teknologi informasi sebagai langkah untuk mempercepat pelayanan publik untuk mewujudkan kesejahteraan bagi segenap elemen bangsa.

Pengadaan barang/jasa pemerintah harus dilakukan secara kredibel melalui pengaturan yang baik, independen (tidak berpihak) serta menjamin terjadinya interaksi ekonomi dan sosial antara para pihak terkait secara adil, transparan, profesional dan akuntabel. Pengadaan yang kredibel juga berarti mencegah adanya persaingan usaha yang tidak sehat di kalangan pelaku usaha dan mengandung unsur-unsur pencegahan Korupsi, Kolusi dan Korupsi $(\mathrm{KKN})$ antara aparat pemerintah dengan pelaku usaha. Dengan pengadaan yang kredibel, kita semua bisa percaya bahwa:|

1. Pengadaan yang dilakukan oleh orang yang benar, artinya pengadaan dilakukan dengan proses yang tepat, oleh pegawai yang memiliki keahlian sesuai kualifikasi yang ditentukan;

2. Pengadaan berhasil mendapatkan barang/jasa yang benar dari penyedia yang benar, artinya penyedia adalah pihak yang memiliki kualifikasi dalam menyediakan barang/jasa sesuai kualitas yang diharapkan;

3. Pengadaan dilakukan pada harga yang benar, artinya telah tercipta mekanisme persaingan sempurna untuk menghasilkan transaksi pada tingkat harga yang wajar.

Untuk dapat terlaksananya proses pengadaan barang dan jasa pemerintah dengan baik, pemerintah menetapkan Perpres Nomor 
157 Tahun 2014 tentang Lembaga Kebijakan Pengadaan Barang/ Jasa Pemerintah (LKPP), yang dibentuk dengan pertimbangan sebagai berikut:

1. Agar pengadaan barang/jasa pemerintah yang dibiayai Anggaran Pendapatan Belanja Negara (APBN) dan Anggaran Pendapatan Belanja Daerah (APBD) dapat dilaksanakan dengan lebih efektif dan efisien serta lebih mengutamakan penerapan prinsip-prinsip persaingan usaha yang sehat, transparan, terbuka dan perlakuan yang adil bagi semua pihak, diperlukan perencanaan, pengembangan dan penyusunan strategi, penentuan kebijakan serta aturan perundangan pengadaan barang/ jasa pemerintah yang sesuai dengan tuntutan dan perkembangan lingkungan internal maupun eksternal secara berkelanjutan, berkala, terpadu, terarah dan terkoordinasi;

2. Bahwa mengingat lingkup dan cakupan pengadaan barang/jasa pemerintah merupakan permasalahan lintas institusi dan lintas sektor yang memiliki dampak langsung bagi pengembangan usaha kecil, produksi dalam negeri, dan pengembangan iklim dan dunia usaha pada umumnya, maka dipandang perlu untuk dibentuk Lembaga Kebijakan Pengadaan Barang/Jasa Pemerintah (LKPP).

Dalam melaksanakan tugasnya LKPP mempunyai fungsi untuk: (a) Penyusunan dan perumusan serta penentuan kebijakan dan standar prosedur di bidang pengadaan barang/jasa pemerintah termasuk pengadaan badan usaha dalam rangka kerja sama pemerintah dengan badan usaha; (b) Penyusunan dan perumusan strategi serta penentuan kebijakan pembinaan sumber daya manusia di bidang pengadaan barang/jasa pemerintah; (c) Pemantauan dan evaluasi pelaksanaannya; (d) Pembinaan dan pengembangan sistem informasi serta pengawasan penyelenggaraan pengadaan barang/jasa pemerintah secara elektronik; (e) Pemberian bimbingan teknis, advokasi, dan pendapat hukum; (f) Pembinaan dan penyelenggaraan dukungan administrasi 
kepada seluruh unit organisasi di LKPP; (g) Pengawasan atas pelaksanaan tugas LKPP.

Peranan LKPP dalam kaitannya dengan perekonomian nasional maupun secara global jelas sangat krusial karena dengan lembaga ini dapat mendorong laju investasi di Indonesia. Selain itu, tingkat kepercayaan (trust) terhadap lembaga negara akan dapat meningkat. LKPP sebagai lembaga kepemerintahan nonkementerian yang bertanggung jawab kepada Presiden mempunyai peran pengawasan untuk tegaknya peraturan pengadaan barang dan jasa. Sejalan dengan pentingnya pengawasan, penulis sependapat dengan Travis Hirschi bahwa diperlukan pengawasan yang kuat untuk mencegah terjadinya kejahatan "The stronger these bonds, the less likelihood of delinquency." Untuk mencegah terjadinya kejahatan tersebut, dibutuhkan attachment, commitment, involment dan belief. Tingkah laku jahat timbul karena tidak adanya keterikatan atau kurangnya keterikatan moral pelaku terhadap masyarakat serta lemahnya ikatan-ikatan yang berkaitan dengan tingkah laku, "Weakness in any of the bonds was associated with delinquent behavior." (Topo Santoso, 2001: 86).

Peranan lembaga/perangkat hukum dalam menegakkan semua ketentuan hukum yang berlaku terhadap pengadaan barang/jasa pemerintah harus dilakukan dengan komitmen yang kuat, karena akan menjadi sangat sulit apabila lembaga/perangkat hukum yang menegakkan peraturan tersebut tidak punya kekuatan moral yang baik dan tidak sanggup mengambil risiko dari penegakan hukum yang dilakukannya. Ada beberapa faktor yang mempengaruhi penegakan hukum yang dapat berdampak positif maupun negatif, yakni: (a) Faktor hukumnya sendiri; (b) Faktor penegak hukumnya; (c) Faktor sarana atau fasilitas; (d) Faktor masyarakatnya; dan (e) Faktor kebudayaan. (Soerjono Soekanto, 2010: 70).

Kelima faktor tersebut mempunyai pengaruh terhadap penegakan hukum, baik positif maupun negatif. Dalam hal ini, faktor penegak hukum bersifat sentral. Hal ini disebabkan karena undang-undang yang disusun oleh penegak hukum, penerapannya dilaksanakan oleh 
penegak hukum itu sendiri dan penegak hukum dianggap sebagai golongan panutan hukum oleh masyarakat. Hukum yang baik adalah hukum yang mendatangkan keadilan dan manfaat bagi masyarakat. Penetapan tentang perilaku yang melanggar hukum senantiasa dilengkapi dengan pembentukan organ-organ penegakannya. Hal ini tergantung pada beberapa faktor di antaranya: (a) Harapan masyarakat yakni apakah penegakan tersebut sesuai atau tidak dengan nilai-nilai masyarakat; (b) Adanya motivasi warga masyarakat untuk melaporkan terjadinya perbuatan melanggar hukum kepada organorgan penegak hukum tersebut; (c) Kemampuan dan kewibawaan daripada organisasi penegak hukum.

Peraturan adalah bentuk tulisan-tulisan yang tertuang dalam rangkaian kata-kata yang harus ditegakkan oleh perangkat/lembaga hukum sebagai kekuatan (power) untuk memaksakan hukum tersebut dilaksanakan dan ditaati. Hukum akan berjalan dengan baik juga harus didukung oleh orang baik yang mempunyai komitmen untuk menegakkan aturan guna mencapai tujuan. Untuk dapat terlaksananya pengadaan barang dan jasa dengan baik, peranan lembaga pengawas harus dapat dilaksanakan dengan maksimal sehingga dapat terwujud tata pemerintahan yang baik dan bersih (Good Governance and Clean Government) seluruh aspek yang terkait dengan kontrol dan pengawasan terhadap kekuasaan yang dimiliki pemerintah dalam menjalankan fungsinya melalui institusi formal dan informal. Pengadaan, sebagai pelaksanaan dari kekuasaan penggunaan anggaran, harus menghasilkan barang/jasa yang dapat dipertanggungjawabkan kepada masyarakat dari segi administrasi, teknis dan keuangan. Karena itu, proses pengadaan dilaksanakan dengan prinsip sebagai berikut: (Agus, 2013:13)

1. Efesien, yaitu pengadaan harus diusahakan dengan menggunakan dana dan daya minimum untuk mencapai kualitas dan sasaran dalam waktu yang ditentukan atau menggunakan dana yang telah ditetapkan untuk mencapai hasil dan sasaran dengan kualitas maksimum;

2. Efektif, yaitu pengadaan harus sesuai dengan kebutuhan dan 
sasaran yang telah ditetapkan serta memberikan manfaat seluas-luasnya;

3. Transparan, yaitu semua ketentuan dan informasi mengenai pengadaan bersifat jelas dan dapat diketahui secara luas oleh penyedia barang/jasa yang berminat serta oleh masyarakat;

4. Terbuka, yaitu pengadaan dapat diikuti semua penyedia barang/jasa yang memenuhi persyaratan/kriteria tertentu berdasarkan ketentuan dan prosedur yang jelas;

5. Bersaing, yaitu melalui persaingan yang sehat di antara sebanyak mungkin penyedia barang/jasa yang setara dan memenuhi persyaratan, sehingga dapat diperoleh barang/jasa yang ditawarkan secara kompetitif dan tidak ada intervensi yang mengganggu terciptanya mekanisme pasar pengadaan;

6. Adil/tidak diskriminatif, yaitu memberi perlakuan yang sama bagi semua calon penyedia barang/jasa dan tidak mengarah untuk keuntungan pihak tertentu dengan tetap mengutamakan kepentingan nasional;

7. Akuntabel, yaitu harus sesuai dengan aturan dan ketentuan yang terkait dengan pengadaan sehingga dapat dipertanggungjawabkan.

Dengan merujuk kepada prinsip tersebut, seharusnya penyalahgunaan keuangan negara dalam pengadaan barang dan jasa bisa dicegah. Namun kasus tindak pidana korupsi di Indonesia sangat tinggi. Nilai kerugian dalam kasus penyalahgunaan anggaran yang terjadi di Indonesia mencapai Rp.203,9 triliun, yang berasal dari 2.321 kasus, dengan melibatkan 3.109 terdakwa. Kerugian negara ini belum menghitung biaya sosial korupsi. Dengan denda Rp.21,26 triliun, berarti masih ada bolong yang harus disubsidi sebesar Rp.182,64 triliun, dampak korupsi akan jauh lebih besar jika dihitung berdasarkan biaya sosial korupsi dari pada kerugian negara saja. Perkiraan biaya sosial korupsi dapat dilakukan dengan mengalikan kerugian negara dengan angka pengali 2,5 kali lipat (beritagar, diakses tanggal 6 April 2017). Sedangkan data kasus korupsi dari media online 
Liputan 6 disebutkan, bahwa kasus korupsi yang telah diputus oleh Mahkamah Agung (MA) dari 2014-2015 sebanyak 803 kasus. Jumlah ini meningkat jauh dibandingkan tahun sebelumnya. (http:// www.cnn.indonesia.com/nasional/2016, diakses tanggal 6 april 2017).

Tingginya kasus korupsi di Indonesia jelas menjadi preseden buruk bagi perekonomian di Indonesia. Pengelolaan keuangan negara sesuai dengan prinsip-prinsip good governance menjadi bingkai bagi penyelenggaraan kesejahteraan rakyat dalam negara kesejahteraan (welfare state). Namun, pembaharuan visi dan sistem pengelolaan keuangan negara hanya akan berhasil apabila ditempatkan sebagai bagian integral dari reformasi sistem dan kultur birokrasi pemerintahan secara menyeluruh.

Proses pengadaan barang dan jasa harus dilaksanakan melalui proses yang benar serta harus dijalankan oleh sumber daya manusia yang memenuhi persyaratan yang ditetapkan oleh undang-undang serta cakap untuk melaksanakannya. Hal tersebut tidak berlebihan karena proses dan sistem pengadaan ini adalah pengelolaan keuangan negara yang jumlahnya sangat besar, dengan ketidakpahaman terhadap proses tersebut akan menyebabkan terjadinya pelanggaran ketentuan yang berdampak pada kerugian terhadap keuangan negara.

Penyalahgunaan keuangan negara merupakan tindakan yang melawan hukum dan merupakan perbuatan yang bertentangan dengan Undang-Undang Nomor 20 Tahun 2001 tentang perubahan atas Undang-undang Nomor 31 Tahun 1999 tentang Pemberantasan Tindak Pidana Korupsi yang dirumuskan bahwa setiap perbuatan seseorang atau badan hukum yang melawan hukum melakukan perbuatan memperkaya diri sendiri atau orang lain atau suatu badan yang secara langsung merugikan keuangan negara dan atau perekonomian negara atau diketahui patut disangka olehnya bahwa perbuatan tersebut merugikan keuangan negara. Sejalan dengan pengertian tersebut Baharudin Lopa (1997: 6) mengemukakan tindak pidana korupsi adalah tindak pidana yang dengan penyuapan manipulasi 
dan perbuatan-perbuatan melawan hukum yang merugikan atau dapat merugikan keuangan negara atau perekonomian negara, merugikan kesejahteraan atau kepentingan rakyat/umum.

Undang-undang Nomor 20 tahun 2001 dalam penjelasan pasal demi pasal disebutkan bahwa korupsi di Indonesia terjadi secara sistematik dan meluas sehingga tidak hanya merugikan keuangan negara, tetapi juga telah melanggar hak-hak sosial dan ekonomi masyarakat secara luas. Peranan lembaga-lembaga pengawas harus dapat menjalin sinergitas dan membuka informasi kepada perangkat hukum (Kepolisian, Kejaksaan, dan KPK) untuk bersama-sama membangun sistem yang bersifat netral terbebas dari intervensi kekuasaan terhadap proses penegakan hukum.

Pemberantasan korupsi harus dilakukan dengan cara yang khusus, antara lain dengan penerapan sistem pembuktian terbalik, -dimana pembuktian yang dibebankan kepada terdakwa-, serta ketentuan dalam tindak pidana korupsi merupakan ketentuan yang bersifat "premium remedium" serta mengandung sifat prevensi khusus. Melalui proses penegakan hukum yang netral dan konsisten dari lembaga/perangkat hukum diharapkan proses pengadaan barang dan jasa pemerintah dapat terlaksana sesuai ketentuan hukum yang berlaku tanpa harus menimbulkan luka hukum yang berdampak pada hasil pelaksanaan yang tidak sesuai dengan spesifikasi yang telah ditentukan yang berakibat pada timbulnya kerugian negara.

\section{Pertanggungjawaban Pidana Terhadap Penyalahgu- naan Wewenang pada Pengadaan Barang dan Jasa.}

Setiap perbuatan mempunyai konsekuensi yang harus dipertanggungjawabkan menurut ketentuan hukum yang berlaku. Berbicara mengenai pertanggungjawaban dalam hukum pidana, terdapat dua pandangan yaitu monistis yang dikemukakan oleh Simon yang merumuskan strafbaar feit sebagai "Eene strafbaar gestelde, onrechtmatige, met schuld in verband staande handeling van een torekening vatbaar persoon " (Suatu perbuatan yang oleh hukum diancam dengan hukuman, bertentangan dengan hukum, dilakukan oleh 
seorang yang bersalah dan orang itu dianggap bertanggung jawab atas perbuatannya). Menurut aliran monisme, unsur-unsur strafbaar feit itu meliputi baik unsur perbuatan yang lazim dinamakan unsur objektif, maupun unsur pembuat, yang lazim dinamakan unsur subjektif. Karena itu, dicampurnya unsur pembuatnya, maka dapatlah disimpulkan bahwa strafbaar feit adalah sama dengan syarat-syarat penjatuhan pidana, sehingga seolah-olah dianggap bahwa kalau terjadi straafbaar feit, maka pasti pelakunya dapat dipidana. (Muladi dan Dwidja Priyatno, 2015: 63).

Pengadaan barang dan jasa terdiri dari beberapa subjek hukum yang bisa berdiri sendiri maupun secara bersama-sama, yang mempunyai akibat hukum dan harus dipertanggungjawabkan. Permasalahan hukum yang timbul dari pengadaan barang dan jasa banyak sekali yang berakhir di 'kursi pesakitan' dan harus mendekam di 'Hotel Prodeo'. Terjadinya penyimpangan hukum yang dilakukan oleh para pelaksana pengadaan barang dan jasa pemerintah, baik dilakukan secara sendiri maupun secara bersama-sama. Proses terjadinya pengadaan barang dan jasa pemerintah dilaksanakan melalui sistem yang dimulai dari merencanakan sampai selesainya seluruh kegiatan, proses tersebut dilaksanakan oleh:

1. Pengguna Anggaran (PA) adalah pejabat pemegang kewenangan penggunaan anggaran Kementerian/Lembaga/Satuan Kerja perangkat Daerah atau pejabat yang disamakan pada institusi pengguna APBN/APBD;

2. Kuasa Pengguna Anggaran (KPA) adalah pejabat yang ditetapkan oleh PA untuk menggunakan APBN atau ditetapkan oleh kepala daerah untuk menggunakan APBD;

3. Pejabat Pembuat Komitmen (PPK) adalah pejabat yang bertanggung jawab atas pelaksanaan pengadaan barang/jasa;

4. Unit Layanan Pengadaan (ULP) adalah unit organisasi Kementerian/Lembaga/Pemerintah Daerah/Institusi yang berfungsi melaksanakan pengadaan barang/jasa yang bersifat permanen, dapat berdiri sendiri atau melekat pada unit yang sudah ada; 
5. Pejabat Pengadaan adalah personel yang ditunjuk untuk melaksanakan Pengadaan Langsung, Penunjukan Langsung, dan e-Purchasing;

6. Panitia/Pejabat Penerima Hasil Pekerjaan adalah panitia/pejabat yang ditetapkan oleh PA/KPA yang bertugas memeriksa dan menerima hasil pekerjaan;

7. Aparat Pengawas Intern Pemerintah (APIP) atau pengawas intern adalah aparat yang melakukan pengawasan melalui audit, reviu, evaluasi, pemantauan, dan kegiatan pengawasan lain terhadap penyelenggaraan tugas dan fungsi organisasi;

8. Penyedia Barang/Jasa adalah badan usaha atau orang perseorangan yang menyediakan barang/pekerjaan konstruksi/jasa konsultansi/jasa lainnya.

Kasus penyalahgunaan wewenang terhadap pengadaan barang dan jasa pemerintah yang terjadi di Provinsi Jambi hanya sebagian kecil dari jumlah kasus-kasus yang sama terjadi di Indonesia. Penulis berpendapat diperlukan pendampingan dan asistensi dari lembaga pengawas pada saat sebelum, sedang, dan sesudah proses pelaksanaan pengadaan barang dan jasa. Penulis mencermati bahwa masih adanya ketidakpahaman dan kurangnya ketelitian dari para pejabat pengadaan barang dan jasa terhadap proses perencanaan sampai kepada pelaksanaannya. Permasalahan lain pada pengadaan barang dan jasa adalah munculnya pandangan (mindset) bahwa anggaran yang dialokasikan untuk $\mathrm{K} / \mathrm{L} / \mathrm{D} / \mathrm{N}$ merupakan "kue" yang dapat dinikmati sesuka hati adalah pandangan yang keliru karena anggaran yang dikeluarkan dan dialokasikan negara untuk K/L/D/N adalah anggaran untuk menggerakkan organisasi tersebut dalam rangka membantu proses pelayanan kepada masyarakat (stake holder) untuk mencapai kesejahteraan sebagaimana yang tertuang dalam UUD 1945.

Pengadaan barang dan jasa pemerintah merupakan sistem dalam tata pengelolaan anggaran negara yang harus dilakukan dengan sesuai dengan ketentuan yang berlaku, apabila tidak ditaati maka akan 
ada risiko hukum yang harus diterima terhadap penyalahgunaan wewenang tersebut. Bentuk pelanggaran hukum yang dilakukan, antara lain berupa menerima suap, gratifikasi dan menyalahgunakan kewenangan dengan melakukan penggelapan terhadap anggaran negara. Dari beberapa proses pengadaan barang dan jasa pemerintah yang penulis amati, terdapat dua faktor yang menyebabkan hal tersebut terjadi, yaitu pertama, ketidakpahaman terhadap proses, prosedur dan ketentuan tentang pengelolaan anggaran sehingga terjadi kesalahan pada administrasi dan penggunaannya. Kedua, unsur kesengajaan yaitu dengan menyiasati dan melakukan mark up dan pemalsuan dokumen dengan membuat laporan secara fiktif.

Pengadaan barang dan jasa pemerintah pada hakikatnya merupakan upaya yang diwakili oleh PPK untuk mendapatkan barang yang diinginkan sesuai dengan peruntukannya dan menjadi tujuan utama dari proses tersebut. Agar esensi pengadaan barang dan jasa tersebut dapat dilaksanakan sebaik-baiknya maka kedua belah pihak yaitu PPK dan penyedia barang dan jasa harus berpedoman pada aturan hukum pengadaan barang dan jasa, tidak boleh membuat kesepakatan-kesepakatan yang bertentangan dengan hukum dan ketentuan yang berlaku. Mencermati tahap pengadaan barang dan jasa tersebut, terdapat tiga aspek hukum terhadap pengadaan barang dan jasa yaitu: (a) Aspek hukum administrasi; (b) Aspek hukum pidana, dan (c) Aspek hukum perdata. (http://lib.ui.ac.id/file?file=digital, diunduh tanggal 8 April 2017).

Tingginya kasus penyalahgunaan kewenangan yang terjadi pada pengadaan barang dan jasa pemerintah sehingga menyebabkan kerugian keuangan negara, menurut pendapat penulis disebabkan karena lemahnya peranan pengawas dan kurangnya kesadaran hukum dari para pelaksana pengadaan barang dan jasa tersebut. Syed Hussein menulis bahwa seorang pembaru Cina yang bernama Wang An Shih (1021-1086) terkesan oleh dua sumber korupsi yaitu bad laws and bad man. Menurut pendapat tentang bad man lebih besar pengaruhnya dari bad laws. (Andi Hamzah, 2007;41).

Untuk dapat dikatakan bahwa telah terjadi perbuatan melawan hukum pada pelaksanaan pengadaan barang dan jasa pemerintah ha- 
rus dipenuhinya unsur-unsur perbuatan melawan hukum, yaitu: (a) Perbuatan melawan hukum; (b) Harus ada kesalahan pelaku; (c) Harus ada kerugian. (Theodarus M. Tuanakotta, 2009: 73). Secara dogmatis dapat dikatakan bahwa dalam hukum pidana, unsur kesalahan harus ada, sebagai dasar untuk memidana si pembuat. Sejalan dengan itu menurut Sauer ada tiga trias (pengertian) dalam hukum pidana, yaitu: (a) Sifat melawan hukum; (b) Kesalahan (schuld); (c) Pidana (strafe). Pengertian perbuatan pidana tidak termasuk hal pertanggungjawaban. Perbuatan pidana hanya menunjuk kepada dilarangnya perbuatan (Muladi, Dwidja Prayitno, 2009: 70).

Sistem pertanggungjawaban pada hukum pidana menurut Ruslan Saleh tidak ada gunanya untuk mempertanggungjawabkan terdakwa atas perbuatannya apabila perbuatan itu sendiri tidak bersifat melawan hukum. Maka lebih lanjut dapat dikatakan bahwa terlebih dahulu harus ada kepastian tentang adanya perbuatan pidana, dan kemudian semua unsur-unsur kesalahan harus dihubungkan pula dengan perbuatan pidana yang dilakukan, sehingga untuk adanya kesalahan yang mengakibatkan dipidananya terdakwa maka haruslah:

1. Melakukan perbuatan pidana;

2. Mampu bertanggung jawab;

3. Dengan kesengajaan atau kealpaan, dan

4. Tidak adanya alasan pemaaf.

Berdasarkan uraian tersebut, jika keempat unsur di atas ada, maka orang yang bersangkutan atau pelaku tindak pidana dimaksud dapat dinyatakan mempunyai pertanggungjawaban pidana, sehingga ia dapat dipidana. Orang yang dapat dituntut di pengadilan dan dijatuhi pidana, haruslah melakukan tindak pidana dengan kesalahan. Kesalahan dapat dibedakan menjadi tiga, yaitu: (a) Kemampuan bertanggung jawab; (b) Sengaja (Dolus/Opzet) dan lalai (Culpa/ Alpa); (c) Tidak ada alasan pemaaf.

Terpenuhinya unsur kesalahan dalam pengadaan barang dan jasa pemerintah harus dipertanggungjawabkan. Sistem pertanggung- 
jawaban pidana terhadap pengadaan barang dan jasa pemerintah ditetapkan tiga sanksi yaitu:

1. Penyalahgunaan terhadap pengadaan barang dan jasa oleh penyedia yaitu sanksi berupa pemuatan dalam daftar hitam selama dua tahun kalender. Daftar hitam adalah daftar yang memuat identitas penyedia barang/jasa dan penerbit jaminan yang dikenakan sanksi oleh Pengguna Anggaran/Kuasa Pengguna Anggaran berupa tidak dapat ikut serta dalam proses pengadaan barang/jasa di seluruh $\mathrm{K} / \mathrm{L} / \mathrm{D} / \mathrm{I}$;

2. Gugatan secara perdata dan atau $\mathrm{K} / \mathrm{L} / \mathrm{D} / \mathrm{I}$ dapat mengajukan gugatan secara perdata kepada penyedia barang/jasa sesuai dengan peraturan perundang-undangan;

3. Sanksi pidana sebagaimana yang tercantum dalam KUHP maupun dalam UU Nomor 20 tahun 2001.

Penegakan hukum terhadap penyalahgunaan kewenangan yang timbul dari pengadaan barang dan jasa harus dilakukan secara tegas dan tanpa diskriminasi serta harus dilakukan secara terus-menerus, sehingga diharapkan adanya efek jera agar tidak mengulangi perbuatan tersebut. Tumbuhnya kesadaran untuk berani mengatakan tidak kepada segala bentuk penyelewengan dalam pelaksanaan dan penggunaan anggaran akan berdampak tumbuhnya kepercayaan (trust) dari bangsa lain kepada Indonesia untuk mewujudkan Indonesia yang sejahtera, tertib dan patuh hukum sebagai syarat good governance and clean governance.

Untuk mewujudkan syarat pemerintahan yang baik adalah tidak terjadinya Korupsi, Kolusi dan Nepotisme (KKN). Upaya aparat penegak hukum terus-menerus dilakukan, namun realitas yang kita hadapi berbanding lurus dengan kasus yang terjadi. Kesejahteraan dapat dicapai apabila pemerintah dapat bersinergi dan saling mendukung proses penyelenggaraan kekuasaan dan kewenangan yang akuntabilitas, transparan, terbuka, bertanggung jawab. Pemerintah yang efektif tergantung pada legitimasi yang diperoleh dari parti- 
sipasi yang berbasis luas, keadilan dan akuntabilitas beranjak dari pengertian governance sebagai cara atau penggunaan atau pelaksanaan di atas. Dengan demikian good governance mengandung makna suatu cara dan pelaksanaan government yang baik, baik dalam arti tindakan atau perilaku para stakeholder dalam menjalankan pemerintahan (government) berlandaskan etika dan moral (Sadjijono, 2005:181).

Menurut teori tentang moral yang dikemukakan oleh JJ. H. Bruggink, mengartikan moral sebagai keseluruhan kaidah dan nilai berkenaan dengan ihwal "baik" atau perbuatan baik manusia, perbuatan dimaksud mencakup merasa, berpikir atau berbicara yang apabila perbuatan itu memenuhi kaidah atau nilai tersebut berarti baik, dan apabila tidak memenuhi kaidah atau nilai (sebaliknya) berarti perbuatan seseorang atau pribadi dari orang itu dinilai sebagai jahat atau jelek. Kaidah dan nilai ini adalah konseptual yang mewujudkan bagian dari kehidupan rohani manusia (Sadjijono, 2005:183).

Ketentuan-ketentuan yang mengatur tentang pelaksanaan pengadaan barang dan jasa agar tidak terjadi penyalahgunaan kewenangan menjadi privilege. Rendahnya pemahaman dan pengetahuan para panitia pengadaan barang dan jasa tentang ketentuan yang harus dilaksanakan dalam proses pengadaan barang dan jasa yang dimulai dari perencanaan sampai kepada pelaksanaan. Selain itu masih sulit untuk menghilangkan budaya meminta jatah dan bagi-bagi komisi. Untuk menghilangkan budaya tersebut dibutuhkan ketegasan dari para pemangku kepentingan untuk berani menerapkan sanksi yang tegas apabila ditemukan perilaku oknum-oknum yang menyalahgunakan kewenangannya untuk memuaskan kepentingan pribadi.

Mengubah budaya serta kebiasaan bagi-bagi jatah atau bagi proyek harus dihilangkan karena pembangunan dilaksanakan untuk menghilangkan kesenjangan terhadap sarana dan prasarana yang dimiliki oleh daerah perkotaan dengan daerah pedesaan. Namun di tengah giatnya pemerintah untuk membangun sarana dan prasarana tersebut, masih ada sejumlah oknum yang memanfaatkan situasi untuk memperkaya diri sendiri dengan melakukan tindakan yang bertentangan dengan hukum yang berlaku. 
Dalam upaya mengubah budaya dan kebiasaan tersebut, menurut penulis, penerapan hukum pidana akan lebih efektif membuat perubahan tersebut karena hukum pidana mempunyai sanksi berupa kurungan dan denda yang dapat diterapkan secara sendiri-sendiri maupun secara bersama-sama. Keberadaan hukum tidak dapat dipisahkan dari masyarakat ubi societas, ibi ius (di mana ada masyarakat, di situ ada hukum). Selain itu, hukum berfungsi sebagai sarana pengendalian sosial, yaitu fungsi hukum yang menjalankan tugas untuk mempertahankan ketertiban atau pola kehidupan yang ada. Roscoe Pound mengatakan bahwa secara garis besar fungsi hukum dibagi menjadi dua, yaitu hukum sebagai alat perekayasa sosial masyarakat (Law as a tool of social engginering) dan hukum sebagai alat kontrol masyarakat (Law as a tool of social control). Hukum diharapkan dapat berperan mengubah nilai-nilai sosial dalam masyarakat. Hukum sebagai alat kontrol sosial memberikan arti bahwa ia merupakan sesuatu yang dapat menetapkan tingkah laku manusia dan mengubah tingkah laku menjadi lebih baik.

Dalam proses modernisasi dan pembangunan ekonomi yang kian meningkat, muncul perkembangan baru dalam kaitannya dengan ruang lingkup dan fungsi hukum pidana dan sanksi pidana. Hukum pidana dalam hal ini digunakan sebagai sarana untuk meningkatkan rasa tanggung jawab negara dalam mengelola kehidupan masyarakat modern secara kompleks. Sanksi pidana antara lain digunakan secara maksimal untuk mendukung norma hukum administratif dalam berbagai hal. Inilah yang dinamakan administrative penal law yang masuk dalam ruang lingkup public welfare offenses.

Pengadaan barang dan jasa yang dilaksanakan oleh pemerintah sebagai langkah dan upaya yang dilakukan untuk memenuhi kesejahteraan masyarakatnya, Indonesia sebagai negara yang menganut konsep kesejahteraan, maka pemerintah Indonesia juga diwajibkan untuk menyejahterakan rakyatnya. Kewajiban ini sudah mendapatkan landasan konstitusional, Indonesia telah menempatkan dirinya sebagai negara kesejahteraan (welfare state), dimana negara telah mengambil bagian dalam urusan kesejahteraan dan kemakmu- 
ran rakyat. Bahkan sejak awal kemerdekaan Indonesia telah menyatakan dirinya sebagai negara kesejahteraan (welfare state) yang menempatkan peran dan tanggung jawab negara dalam mewujudkan kesejahteraan rakyat.

Dalam negara hukum yang sudah modern seperti sekarang ini, negara tidak hanya bertugas dalam mengurusi masalah keamanan dan ketertiban saja (Negara Penjaga Malam), namun juga mempunyai tugas dalam bidang penyelenggaraan kesejahteraan umum. Negara yang bertugas menyelenggarakan kesejahteraan umum dikenal dengan istilah "negara kesejahteraan" (Welfare State). Negara kesejahteraan Indonesia mempunyai tujuan untuk memajukan kesejahteraan umum dan keadilan sosial yang ditujukan untuk mewujudkan kesejahteraan sosial bagi seluruh rakyat Indonesia. (Teguh Prasetyo, Arie Purnomosidi, 2014: 135-136).

Pertanggungjawaban hukum terhadap kesalahan yang timbul dari proses pengadaan barang dan jasa dapat dilaksanakan oleh perangkat/lembaga hukum sehingga memberikan effective deterent, yakni menciptakan rasa takut terhadap sanksi pidana (terutama kemerdekaan) demi perlindungan masyarakat. Hukum hendaknya melahirkan sebuah keadilan yang memberi kesejukan bagi masyarakat secara umum. Dalam banyak hal telah terjadi bahwa hukum hanya melahirkan luka masyarakat. Sebab dalam hal ini hukum tidaklah dijadikan sebuah landasan kesepakatan moral sekaligus perilaku masyarakat secara menyeluruh. Namun kenyataannya, justru hukum hanya mengundang diskriminatif antara masyarakat dengan kaum penguasa.

Merebaknya perilaku korup yang berniat memperkaya diri sendiri pada pengadaan barang dan jasa sehingga menimbulkan kerugian negara yang sangat besar, adalah sebuah realitas yang membuktikan mandulnya nilai hukum dan hancurnya pranata sosial yang ada. Ini juga didukung dengan kondisi penegakan hukum yang tidak konsisten dan cenderung diskriminatif, sebuah kondisi yang harusnya tidak boleh terjadi. Namun keadaan sudah sedemikian rupa sehingga masyarakat mau tidak mau harus ikut andil dalam memberikan 
dukungan untuk memberikan informasi terhadap penyimpangan pada proses pengadaan barang/jasa pemerintah kepada aparat penegak hukum dan lembaga pengawas. Dengan demikian diharapkan peradilan mampu menjadi pintu gerbang untuk mencapai tujuan kesejahteraan sebagaimana yang menjadi tujuan yang ingin dicapai dalam pengadaan barang dan jasa pemerintah.

Penulis berpendapat bahwa peraturan yang baik harus dijalankan dan disertai juga dengan orang yang baik sehingga hukum dapat bergerak lurus sesuai dengan harapan dan tujuan hukum untuk mencapai keadilan, kemanfaatan dan kepastian hukum.

\section{KESIMPULAN}

Peranan pemerintah merupakan privilege untuk melakukan pengadaan barang/jasa secara kredibel melalui pengaturan yang baik, independen (tidak berpihak) serta menjamin terjadinya interaksi ekonomi sosial diantara pihak terkait secara adil, transparan, profesional dan akuntabel. Pelaksana dalam pengertian orang yang berkompeten pada pengadaan barang dan jasa K/L/D/I harus melalui proses dan persyaratan yang ketat sehingga tidak mudah untuk diintervensi dengan berbagai kepentingan para pihak sehingga arah dan tujuan untuk mencapai kesejahteraan bagi seluruh rakyat Indonesia dapat tercapai.

Sistem pertanggungjawaban pidana pada proses pengadaan barang dan jasa tetap menjadi tanggung jawab individu sesuai dengan tingkatan dan unsur kesalahan yang dilakukan karena unsur kesalahan (schuld) yang pada hakikatnya adalah pertanggungjawaban pidana, yaitu pelanggaran norma yang dilakukan karena kesalahan yang dapat dilihat dari dua sudut; pertama dari akibatnya adalah hal yang dapat dicela, kedua dari hakikatnya adalah hal tidak dihindarinya perbuatan melawan hukum.

\section{Saran}

1. Lembaga/kementerian/departemen/instansi yang melak- 
sanakan proses pengadaan barang dan jasa harus betul-betul memiliki itikad yang baik. Selain itu, setiap pejabat pengadaan yang terlibat dalam pengadaan, disarankan untuk mengikuti pelatihan dan diberi pengetahuan dan keterampilan tentang pengadaan barang dan jasa secara berkala untuk mendapat asistensi agar tidak terjadi pemahaman yang keliru tentang proses pengadaan barang dan jasa tersebut.

2. Pertanggungjawaban pidana terhadap pengadaan barang dan jasa sebaiknya terus dilaksanakan sosialisasi dari LKPP sehingga timbul pemahaman yang benar tentang pengadaan barang dan jasa untuk menghindari terjadinya mark up dan kolusi terhadap pengadaan sehingga menimbulkan kerugian terhadap keuangan negara.

\section{REFERENS I}

Agus Kuncoro, (2013). Begini Tender yang benar, CV. Primaprint, Jogjakarta.

Andi Hamzah, (2007). Pemberantasan korupsi melalui hukum pidana nasional dan internasional, PT. Rajagrafindo Persada, Jakarta.

https://beritagar.id/artikel/berita/kerugian-negara-akibat-korupsi-diindonesia-rp2039-triliun, diunduh tanggal 6 April 2017.

http://www.cnnindonesia.com/nasional/20161228182616-12-

182732/ma-jumlah-perkara-korupsi-meningkat-sepanjang-2016, diunduh tanggal 6 April 2017.

http://lib.ui.ac.id/file?file=digital, diunduh tanggal 8 April 2017.

Muladi, Dwidja Priyatno, (2015). Pertanggungjawaban pidana korporasi, Kencana, Jakarta, edisi ketiga.

Republik Indonesia, 1999, Undang-Undang Nomor 20 Tahun 2001

Tentang Perubahan atas Undang-Undang Nomor 31 Tahun 1999 tentang Tindak Pidana Korupsi.

Republik Indonesia, Kitab Undang-Undang Hukum Pidana.

Republik Indonesia, 2007, Undang-Undang Nomor 17 Tahun 2007 
Tentang Rencana Pembangunan Jangka Panjang dan Nasional Tahun 2005-2025.

Republik Indonesia, 2007, Peraturan Presiden Republik Indonesia Nomor 106 Tahun 2007 tentang Lembaga Kebijakan Pengadaan barang/jasa Pemerintah.

Republik Indonesia, 2010, Peraturan Presiden Nomor 4 Tahun 2015 tentang perubahan ke-empat atas peraturan Presiden Nomor 54 Tahun 2010 tentang pengadaan barang/jasa pemerintah.

Republik Indonesia, 2015, Peraturan Kepala Lembaga Kebijakan Pengadaan Barang/Jasa Pemerintah Nomr 23 Tahun 2015 tentang petunjuk teknis operasional sertifikasi keahlian tingkat dasar pengadaan barang/jasa pemerintah.

Roeslan Saleh, (1982). Pikiran-pikiran Tentang Pertanggungjawaban Pidana, Ghalia Indonesia. Jakarta.

Sarja, (2016). Negara hukum dalam teori dan praktek, Thafamedia, Yogyakarta.

Sadjijono, (2005). Fungsi Kepolisian dalam pelaksanaan Good Governance, laksbang, Yogyakarta.

Soerjono Soekanto, (2010). Faktor-Faktor yang mempengaruhi penegakan hukum, Rajawali Press.

Topo Santoso, (2001). Kriminologi, PT RajaGrafindo, Jakarta.

Teguh Prasetyo, Arie Purnomosidi, (2014). Membangun hukum berdasarkan pancasila, Nusa Media, Bandung.

Theodarus M. Tuanakotta, (2009). Menghitung kerugian keuangan negara dalam tindak pidana korupsi, Salemba Empat, Jakarta. 